\title{
Eukaryotic microbes, principally fungi and labyrinthulomycetes, dominate biomass on bathypelagic marine snow
}

\author{
Alexander B Bochdansky ${ }^{1}$, Melissa A Clouse ${ }^{1}$ and Gerhard J Herndl ${ }^{2}$ \\ ${ }^{1}$ Ocean, Earth and Atmospheric Sciences, Old Dominion University, Norfolk, VA, USA and ${ }^{2}$ Department of \\ Limnology and Bio-Oceanography, Division of Bio-Oceanography, University of Vienna, Vienna, Austria
}

\begin{abstract}
In the bathypelagic realm of the ocean, the role of marine snow as a carbon and energy source for the deep-sea biota and as a potential hotspot of microbial diversity and activity has not received adequate attention. Here, we collected bathypelagic marine snow by gentle gravity filtration of sea water onto $30 \mu \mathrm{m}$ filters from $\sim 1000$ to $3900 \mathrm{~m}$ to investigate the relative distribution of eukaryotic microbes. Compared with sediment traps that select for fast-sinking particles, this method collects particles unbiased by settling velocity. While prokaryotes numerically exceeded eukaryotes on marine snow, eukaryotic microbes belonging to two very distant branches of the eukaryote tree, the fungi and the labyrinthulomycetes, dominated overall biomass. Being tolerant to cold temperature and high hydrostatic pressure, these saprotrophic organisms have the potential to significantly contribute to the degradation of organic matter in the deep sea. Our results demonstrate that the community composition on bathypelagic marine snow differs greatly from that in the ambient water leading to wide ecological niche separation between the two environments.
\end{abstract}

The ISME Journal (2017) 11, 362-373; doi:10.1038/ismej.2016.113; published online 20 September 2016

\section{Introduction}

Deep-sea life is greatly dependent on the particulate organic matter (POM) flux from the euphotic layer. Thus, the quantification of the POM flux into the ocean's interior and the attenuation of POM with depth in the oceanic water column have been major focal points in oceanographic research in large international research programs (for example, Martin et al., 1987; Koeve and Ducklow, 2001; Buesseler and Boyd, 2009). The POM flux in the oceanic water column is typically estimated by collecting particles with sediment traps (Buesseler et al., 2007; Honjo et al., 2008). However, these sediment traps collect fast-sinking particles with much higher efficiency than slowly-sinking particles, while buoyant particles are not collected at all. Recently, we demonstrated that bathypelagic particles in a size range from $400 \mu \mathrm{m}$ to several $\mathrm{mm}$ were more abundant than expected from the number spectrum of smaller particles (Bochdansky et al., 2016). Approximately $30 \%$ of these particles did not contain apparent ballast, such as fecal pellets

Correspondence: AB Bochdansky, Ocean, Earth and Atmospheric Sciences, Old Dominion University, 4600 Elkhorn Avenue, Norfolk, VA 23529, USA.

E-mail: abochdan@odu.edu

Received 11 April 2016; revised 11 July 2016; accepted 13 July 2016; published online 20 September 2016 or dense phytodetritus, but a large amount of transparent exopolymer particles (TEP, Alldredge et al., 1993), which led us to conclude that they are either neutrally buoyant or slow sinking (Bochdansky et al., 2016). Neutrally buoyant or slowly-sinking marine snow has previously been suspected to contribute significantly to the metabolism of the deep sea, providing hotspots of microbial diversity and activity (Baltar et al., 2010; Bochdansky et al., 2010; Burd et al., 2010). Hence, it is likely that the microbial community composition and activity on bathypelagic marine snow is fundamentally different from that of the ambient water. Deep-sea studies examining differences between particle-associated and freely-suspended microbes so far have primarily been based on high-throughput sequencing of the $16 \mathrm{~S}$ and $18 \mathrm{~S}$ rRNA genes. For instance, bacterial, archaeal and eukaryotic microbial communities were found to be significantly different between 0.22 and $3 \mu \mathrm{m}$ fractions in samples from the Puerto Rico trench $(6000 \mathrm{~m})$ (Eloe et al., 2011). The examination of bathypelagic bacterioplankton communities revealed deep phylogenetic differences between particulate fractions $(>0.8-20 \mu \mathrm{m})$ and free-living cells $(0.2-0.8 \mu \mathrm{m})$ (Salazar et al., 2015). Microbial communities of all three domains also differed between sea water samples and sediment trap (particle interceptor traps) contents (Fontanez et al., 2015). In a study employing stable isotope probing, specific particle-associated clades were 
identified that specialize in the degradation of highmolecular weight compounds (Orsi et al., 2016). Recently, Pernice et al. (2016) described a highly variable eukaryotic microbial community composition that was affected by depth, water masses, as well as the number of prokaryotes. It is thus possible that the relative amount and type of marine snow significantly contributes to this observed variability.

In the present study, we addressed the question whether the particular conditions in bathypelagic marine snow, representing oases in the nutritive desert of the bathypelagic realm, lead to altered microbial food web structures on bathypelagic marine snow as compared with the ambient water. We also hypothesized that the abundance relation between prokaryotes and eukaryotes in deep-sea marine snow more closely resembles the one in surface waters rather than the organic nutrient-deprived deep-sea ambient waters. To this end, we examined the relative distribution of eukaryotic microbes in general, as well as three specific subgroups-the kinetoplastids, fungi and labyrinthulomycetes -in bathypelagic marine snow collected on $30 \mu \mathrm{m}$ pore-size filters. The pore size of the filters was selected to filter large volumes of water and to target amorphous marine snow. The rationale for the selection of the three subgroups was as follows. Fungi have been identified in all marine environments including the deep sea, hydrothermal vents, sea ice and in the deep biosphere below the sea floor (for example, Kutty and Philip, 2009; Le Calvez et al., 2009; Edgcomb et al., 2011a; Morgan-Smith et al., 2013; Ciobanu et al., 2014; Rédou et al., 2015; Richards et al., 2015; Hassett and Gradinger, 2016; Tisthammer et al., 2016). While fungi are thought to have a relatively small role in pelagic environments (Newell, 1994; Kirchman, 2008), some reports have shown episodically higher numbers in the water column (Gutiérrez et al., 2011). Of the labyrinthulomycetes, thraustochytrids are often associated with dead phytoplankton debris at the end of a bloom (reviewed in Raghukumar, 2002) where they can be episodically found in such high numbers that they match bacterial biomass (Damare and Raghukumar, 2008). For both groups, marine snow represents a potential nutrientrich substrate that would suit their osmotrophic lifestyle. The third group selected for this study, the kinetoplastids, are heterotrophic flagellates that have consistently been found in deep-sea samples (e.g., Turley et al., 1988; Arndt et al., 2003; Morgan-Smith et al., 2013). In addition, their non-parasitic forms are voracious bacterivores that are often associate with particles (Artolozaga et al., 2000; Boenigk and Arndt, 2002), which makes them prime candidates to populate deep-sea marine snow.

\section{Materials and methods}

Sample collection

Sea water was collected during the MEDEA-2 research expedition to the North Atlantic and Arctic
Basin between 22 June and 22 July 2012 on the RV Pelagia (Royal Netherlands Institute of Sea Research, Figure 1). At the beginning of the cruise, all Niskin bottles were filled with a 5\% bleach solution overnight to remove microbes that may have grown during storage. Collection depths were chosen to target specific bathypelagic water masses (Supplementary Table S1,van Aken, 2000). Immediately after returning on deck, one $25 \mathrm{~L}$ Niskin bottle was removed from the rosette assembly and set aside for gentle gravity filtration. A filter cartridge was connected to the spout and a flow restrictor was put in-line after the cartridge (Supplementary Figure S1). The cartridge was loaded with a $25 \mathrm{~mm}$ diameter, $30 \mu \mathrm{m}$ pore-size polycarbonate filter membrane (type PCT30025100, Sterilitech Corp., Kent, WA, USA). The flow was set to a maximum rate of $100 \mathrm{ml} \mathrm{min}^{-1}$. Although marine snow is defined as $>500 \mu \mathrm{m}$ in size (Alldredge and Silver, 1988), pores or meshes of that size are ineffective because these particles are too fragile to be retained. In contrast, filtration on smaller pore sizes such as 0.2 or $0.8 \mu \mathrm{m}$ filters is limited to much smaller volumes $(\sim 100 \mathrm{ml}$ and $\sim 1 \mathrm{~L}$ on $25 \mathrm{~mm}$ diameter filters, respectively) due to the clogging of the filter pores by TEP and finely suspended material from the ambient water. Approximately 15-21 L were filtered in this manner (see Supplementary Table S1 for volume filtered at each station), and upon inspection, all filters had a visible layer of material. While still in the cartridge, the collected material was preserved on the filter by connecting a syringe containing a $2 \%$ (final concentration) formaldehyde solution in $0.2 \mu \mathrm{m}$ filtered deep-sea water. The filter was gently rinsed with sterile $1 \times$ phosphate-buffered saline and ultrapure water by attaching another set of syringes to the cartridge and by gently moving the water in the

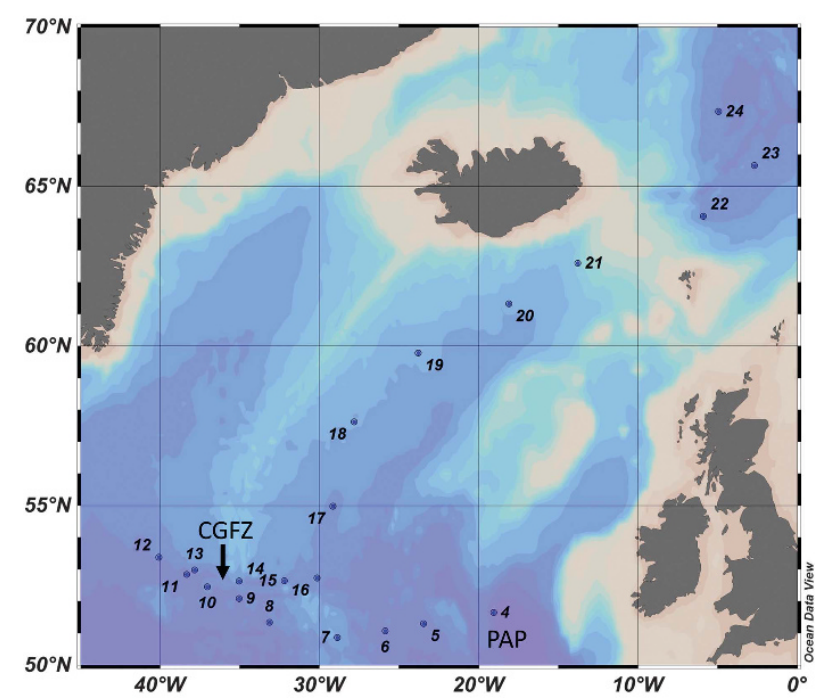

Figure 1 Map of stations at which deep-sea samples of marine snow were taken. Depths are shown in Supplementary Table 1. CGFZ, Charlie Gibbs Fracture Zone; PAP, Porcupine Abyssal Plane. 
same direction as the original flow. Water samples (200-250 $\mathrm{ml}$ each) from the same depths and locations were preserved in $2 \%$ formaldehyde $(\sim 30 \mathrm{~min})$ and subsequently filtered through $25 \mathrm{~mm} 0.2 \mu \mathrm{m}$ pore-size polycarbonate filters (Millipore, Billerica, MA, USA) using a standard filtration manifold. Filters were also rinsed with $1 \times$ phosphatebuffered saline and ultrapure water before being stored at $-80^{\circ} \mathrm{C}$. Samples were returned to Old Dominion University on dry ice where they were stored at $-80^{\circ} \mathrm{C}$ until further processing.

\section{Pretreatment of filters with agarose and EDTA}

Initial microscopic observation revealed that no microbes could be visualized using 4',6-diamidino2-phenylindole (DAPI) despite a visible layer of material on the $30 \mu \mathrm{m}$ pore-size filters. This was due to a thick matrix of TEP which we were able to render permeable by pretreating the filter with a $25 \mathrm{~mm}$ EDTA solution for $15 \mathrm{~min}$ (Cavaliere et al., 2014). Tests were performed with shorter and longer time intervals ( 5 min to 2 days), with 15 min being optimal. EDTA dissolves the TEP by scavenging the cationic bridges of mainly $\mathrm{Ca}^{2+}$ between neighboring TEP chains (Cavaliere et al., 2014; Bar-Zeev et al., 2015). To minimize losses from the filter surface, we covered the filter with agarose according to the catalyzed reporter deposition fluorescence in situ hybridization (CARD-FISH) procedure (Teira et al., 2004; Morgan-Smith et al., 2013) before the EDTA treatment. Agarose forms a very porous molecular mesh that works very well to hold organisms in place but allows EDTA and probes to penetrate. Tests indicated that agarose coating did not negatively affect EDTA permeabilization.

\section{Tyramide signal amplification CARD-FISH}

CARD-FISH was performed to examine the composition of eukaryotic microbes on both the $30 \mu \mathrm{m}$ and $0.2 \mu \mathrm{m}$ filters. As we found a mismatch of the kinetoplastids with the universal eukaryote probe EUK516 (Bochdansky and Huang, 2010; Mukherjee et al., 2015), and some diplonemids displayed a second mismatch (for example, Genbank accession \#KF633466.1 and \#JN542573.1), we designed a new probe (Diplo516) and used the combination of three probes (EKD: EUK516 +KIN516+Diplo516, Supplementary Table S2) to be as inclusive as possible. We evaluated this probe combination with a series of stringency tests on deep-sea samples from the same cruise (5 stations) using the protocol of Hugenholtz et al. (2001) and arrived at an optimal stringency of $40 \%$ formamide concentration (see probe evaluation details in the Supplementary Information). This group hybridizing with the EKD-probe combination will be referred to as 'eukaryotes'. The probe sequences and optimal formamide stringencies used in this study for kinetoplastids (KIN516), fungi (PF2) and labyrinthulomycetes (LabY) are also given in Supplementary Table S2. After the initial agarose coating and EDTA treatment, we followed the CARDFISH protocol using AlexaFluor 488 detailed in Morgan-Smith et al. (2013). Additional permeabilization as previously applied for fungi and the regular FISH protocol is not necessary when using CARDFISH (Jobard et al., 2010; Morgan-Smith et al., 2013). We achieved $100 \%$ success rate of CARD-FISH in detecting fungal cells without permeabilization in tests using bread yeast and a chytrid culture. All treatments were counterstained with DAPI in an antifadent mountant (Vectashield with DAPI, Vector Laboratories, Burlingame, CA, USA). Signals were only considered positive (regarded as an eukaryotic cell) if the green hybridization signal was also colocated with a clearly identifiable DAPI-stained nucleus. Not all probes could be used on all filters, due to a shortage of filter slices after performing formamide, EDTA and agarose tests (see above). For every filter slice, prokaryotes were also enumerated using DAPI and these more numerous and easily identifiable cells served as benchmark values to normalize eukaryotic microbe numbers for each filter slice.

\section{Enumeration and dispersion diagnostics}

Two sets of counts were performed on every filter slice (30 and $0.2 \mu \mathrm{m}$ ). The first set consisted of counting both prokaryotes and eukaryotic microbes at the same time and in the same plane to obtain information on spatial heterogeneity on the filter surfaces. This was done by counting up to 150 entire microscopic fields at the highest magnification (Olympus BX51 epifluorescence microscope (Center Valley, PA, USA), U-LH100HG APO mercury burner, $100 \times$ UPlanSApo objective lens and $\times 20$ ocular magnification). This approach was used to test the hypothesis that organisms that landed on the $30 \mu \mathrm{m}$ filter were not solely random intercepts on the filter membrane but due to the presence of particles. In that case, the dispersion index would be much higher than expected from a random distribution. The distribution of organisms on the $0.2 \mu \mathrm{m}$ filter, in contrast, should have a distribution of organisms on the filter surface closer to random. In other words, the patchy arrangement of microbes on the filter surface is an indicator that particles were captured even if the exact outlines of these particles are not readily detectable. As a dispersion index, we chose the Lloyd index of patchiness (Lloyd, 1967), which has a good dynamic range at highly overdispersed (patchy) distributions (Bochdansky and Bollens, 2004). The Lloyd index of patchiness (Lp) is the ratio of the Lloyd index of mean crowding $(\dot{m})$ divided by the mean $(m)$, or

$$
\mathrm{Lp}=\frac{\dot{m}}{m}=\left[m+\left(\frac{\sigma^{2}}{m}-1\right)\right] m^{-1}
$$


where $\sigma^{2}$ is the variance (Lloyd, 1967). An Lp of 1 means that microbes are randomly distributed on the filter, above 1 they are overdispersed.

A second set of counts was performed at lower $(\times 10$ ocular) magnification to enumerate all protists found on the entire filter slice (up to 300 entire microscopic fields). This improved the enumeration of less represented groups. Length and average width of a subsample of fungi and the labyrinthulomycetes were measured (this included single cells, thalli and sporangia, but did not include any hyphen that permeated the particle matrix, Jobard et al., 2010). Volume calculations were based on prolate spheroid geometry $\left(\pi / 6 \times\right.$ width $^{2} \times$ length $)$ for eukaryotic microbes (Pernice et al., 2015), and on the equation $(\pi / 4) \times$ width $^{2} \times($ length $-($ width/3) $)$ for cocci and bacilli (Bratbak, 1985). Estimates of eukaryotic microbial biomass are minimum estimates of total biomass especially for organisms that may have significant biomass allocated in hyphen structures. Non-parametric tests were used in lieu of Student's $t$-tests because residuals were not normally distributed, or sample size was too small to test for normality of the residuals.

\section{Results}

Prokaryote counts on $30 \mu \mathrm{m}$ filters were highly variable among different microscopic fields, and were significantly more patchy than those observed on $0.2 \mu \mathrm{m}$ filters. The Lp was on average 5.22 (s.d. $=4.33, n=61$ ) on the $30 \mu \mathrm{m}$ filters, and on average 1.39 (s.d. $=0.27, n=59$ ) on $0.2 \mu \mathrm{m}$ filters with the means being significantly different from each other (Wilcoxon signed-rank test, $n=58$, $\mathrm{z}$-score $=6.62, P<0.0001)$. This means that while prokaryotes were only 1.4 times more overdispersed than expected from a random distribution on $0.2 \mu \mathrm{m}$ filters, prokaryotes were 5 times more overdispersed on $30 \mu \mathrm{m}$ filters. The standard deviation of prokaryote numbers for individual fields was also much higher on the $30 \mu \mathrm{m}$ filters ( $83 \%$ of mean) than on the $0.2 \mu \mathrm{m}$ filters (19\% of the mean). This demonstrates that microbes that landed on the $30 \mu \mathrm{m}$ filters were not random intercepts with the filter surface but that parts of aggregates were responsible for the patchy distribution. Figure 2 shows an example of a large particle with embedded microbes under DAPI as found on a $30 \mu \mathrm{m}$ filter; particle boundaries were not always as clear as in that particular case however. This image also demonstrates the typically large amount of transparent exopolymer matrix that holds the particle and microbes together (Figure 2).

Examples of eukaryotic microbes with positive hybridization signals from CARD-FISH are displayed in Figure 3. The ratios between eukaryotic and prokaryotic microbes (normalized eukaryote numbers, NEN) are shown in Figure 4. The differences in NEN between the $0.2 \mu \mathrm{m}$ and the $30 \mu \mathrm{m}$ filters were highly significant for the eukaryotes (Wilcoxon

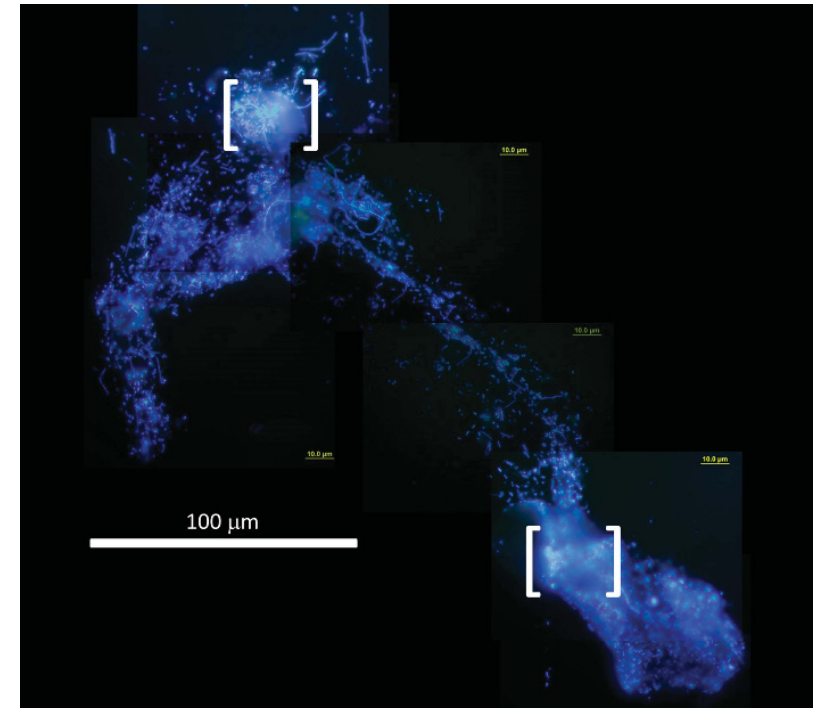

Figure 2 Epifluorescence image mosaic of a bathypelagic particle from $3390 \mathrm{~m}$ collected at the Charlie Gibbs Fracture Zone and retained by a $30 \mu \mathrm{m}$ pore-size filter, pretreated with $25 \mathrm{~mm}$ EDTA, and stained with DAPI. Note: hazy areas [brackets] are not large objects but represent backscatter from the edges of the $30 \mu \mathrm{m}$ filter pores.

signed-rank test, $z$-score $=3.92, P=4.5 \times 10^{-5}$ ), the labyrinthulomycetes (Wilcoxon signed-rank test, $z$-score $=3.46, P=2.7 \times 10^{-4}$ ) and the fungi (Wilcoxon signed-rank test, $Z$-score $=3.48, P=2.5 \times 10^{-4}$ ). Fewer samples were available for kinetoplastids but the difference was still significant between NEN on the 0.2 and the $30 \mu \mathrm{m}$ filters (Mann-Whitney $U$-test, $U=16, P=0.0286$ ). Fungi and labyrinthulomycetes accounted for $\sim 1 / 5$ each of all eukaryotic microbes on particles ( $30 \mu \mathrm{m}$ filters) but for a much lesser extent on the $0.2 \mu \mathrm{m}$ filter samples (Figure 4). The relative enrichment ratios on particles (that is, the enrichment of eukaryotic microbes in excess of the enrichment of prokaryotes, calculated as the ratio between NEN on the $30 \mu \mathrm{m}$ filters and NEN on the $0.2 \mu \mathrm{m}$ filters) were $78,25,42$ and 141 times that of prokaryotes for total eukaryotes, kinetoplastids, labyrinthulomycetes and fungi, respectively (Figure 4).

The volumes of fungi and labyrinthulomycetes were on average $115 \mu \mathrm{m}^{3}$ (s.d. $=203, n=16$ ) and $106 \mu \mathrm{m}^{3}$ (s.d. $=125, n=22$ ), respectively, and thus much larger than those of prokaryotes (cocci: $0.061 \mu^{3}$, s.d. $=0.073, n=90$; bacilli: $0.079 \mu \mathrm{m}^{3}$, s.d. $=0.089, n=88$ ) in the same samples. For fungi and labyrinthulomycetes, the volumes were measured for each occurrence, which may include more than one cell per occurrence (for example, in a sporangium or thallus).

\section{Discussion}

Methodological considerations

The use of $30 \mu \mathrm{m}$ pore-size filters in combination with gentle gravity filtration was a suitable 

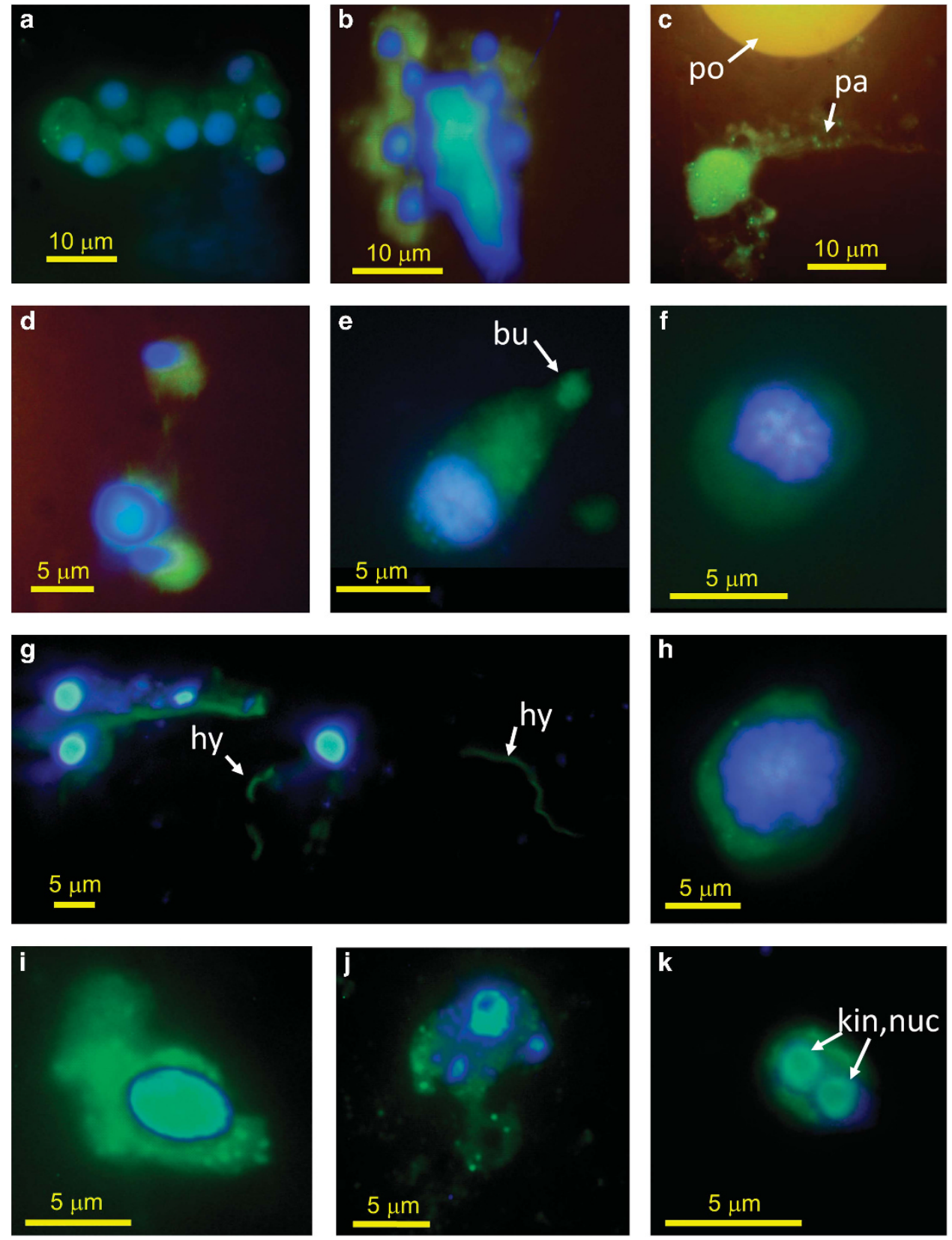

Figure 3 Examples of protists hybridized with four different probes. Images are overlays of the CARD-FISH probes (green) and DAPI counterstain (blue). (a-d) Organisms hybridizing with the LabY probe for labyrinthulomycetes; (c) green channel only, po=filter pore, pa = particle fragment. (e-h) Organisms hybridizing with the broad fungal probe PF2. (e) bu = cell shape is similar to a yeast cell forming a bud; (g) hy = structures that appear to be fungal hyphae similar to those shown in Jobard et al. (2010). As only ribosomes embedded in cytoplasma (and not chitin cell walls) light up in CARD-FISH, hyphae may appear thinner than when chitin stains are used. (i and j) Organisms hybridizing with the universal eukaryote probe combination to include kinetoplastids and diplonemids (probe: EKD). (k) Kinetoplastid showing the kinetoplast (kin), a large mitochondrion and the nucleus (nuc) side by side (probe: KIN516).

compromise to sample marine snow aggregates from large volumes of water, because the large filter pores let single organisms pass, but retained some marine snow. However, these aggregates are too fragile to be collected quantitatively with this method as they can easily fragment even under the gentlest collection and fixation protocols on filters. A better method is to visually locate these particles in the water column and then collect them selectively with suction samplers or syringes, being careful to exclude ambient water. This type of collection is either carried out by divers (for example, Bochdansky and Herndl, 1992; Silver, 2015) or by submersibles (Silver and Alldredge, 1981; Alldredge and Youngbluth, 1985). However, the bathypelagic ocean is beyond the reach of divers, and submersibles are prohibitively expensive to deploy over large ocean regions as encompassed in this study. In addition, 

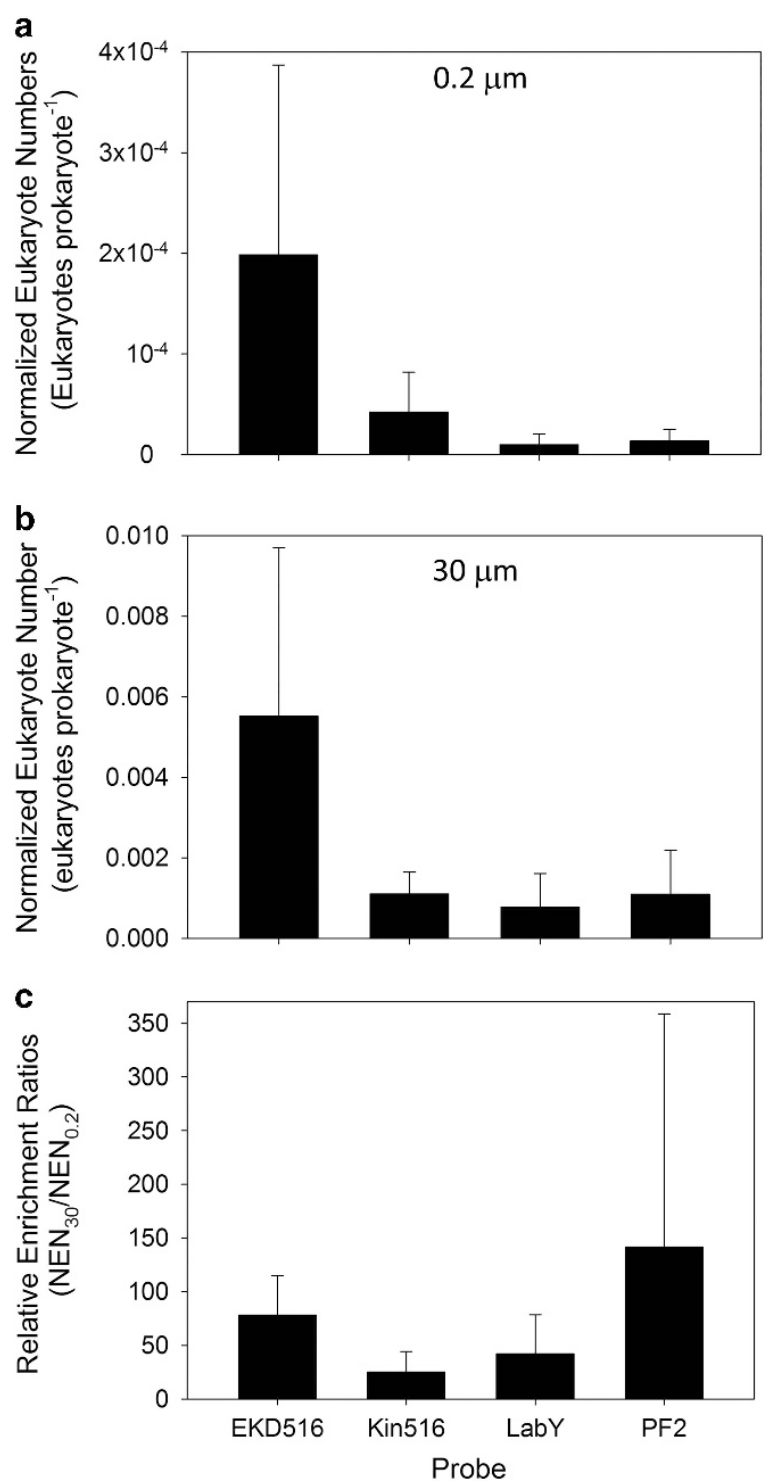

Figure 4 NEN (number of eukaryotic microbes divided by number of prokaryotes) on $0.2 \mu \mathrm{m}$ pore-size (a) and on $30 \mu \mathrm{m}$ pore-size (b) filters. The ratio between $\mathrm{NEN}_{30}$ and $\mathrm{NEN}_{0.2}$ provides the relative enrichment ratios on marine snow (c). This ratio is an indicator for how much more eukaryotes are enriched in particles over the already highly enriched prokaryotes. It demonstrates that the contrast between the particles and ambient water environments are much larger for eukaryote than for prokaryotic numbers. Error bars are standard deviations.

marine snow less than a few millimeters is very difficult to collect from a submersible (Silver and Alldredge, 1981; Alldredge and Youngbluth, 1985) so that a large portion of relevant particles $(>400 \mu \mathrm{m})$ is unaccounted for (Bochdansky et al., 2016). Although we concede some inefficiency in our sampling protocol, we are also confident that marine snow was retained by our method. The organisms on the $30 \mu \mathrm{m}$ pore-size filters were much more overdispersed than those on the $0.2 \mu \mathrm{m}$ filters, rejecting the notion that these organisms were just randomly captured by direct interception with the filter surface. In addition, a thick layer of TEP (the invisible matrix that typically holds marine snow together) was present on all $30 \mu \mathrm{m}$ pore-size filters-so much so that EDTA had to be used to allow probes and nucleic acid stains to reach the embedded microorganisms. Normalizing all counts to the more abundant prokaryotes leads to relative enrichment ratios of eukaryotic microbes in an unbiased manner and also circumvents the problem of uneven material collection on different parts of the filters.

\section{Kinetoplastids}

Non-parasitic species of this group of flagellates are known to feed well on bacteria attached to particles (Artolozaga et al., 2000; Boenigk and Arndt, 2002) and in biofilms (Chavez-Dozal et al., 2013). Members of this group (Bodo sp., Neobodo designis) do not feed well on freely-suspended cells but prefer to feed on attached prokaryotes (Caron, 1987; Bochdansky and Clouse, 2015). The ratio of eukaryotic microbes to prokaryotes on particles in this study is very similar to those found in surface environments (for example, Gasol et al., 1997) where bacterivores together with viruses have an important role in controlling prokaryotic populations (for example, Fuhrman and Noble, 1995). Thus, it is likely that bacterivores have the same capacity to control prokaryotes on marine snow as in surface waters. A recent study demonstrated that kinetoplastids are also very abundant in hypolimnetic systems where they can represent up to $44 \%$ of total flagellates (Mukherjee et al., 2015). It would thus be very interesting to further study their association with particles in freshwater systems.

\section{Fungi}

In our analysis, approximately one fungal cell occurs for every 1000 prokaryotes on marine snow making their biomass approximately at par with that of prokaryotes (Table 1). This raises the intriguing question on how important fungi are for the degradation of organic material in the deep sea. Many species of fungi are known to be saprotrophic, and their osmotrophic food acquisition is suitable for substrates they can attach to and on which their extracellular enzymes are not lost to the environment by diffusion (Richards et al., 2015). Fungi are often better than bacteria at breaking down recalcitrant organic material (Clipson et al., 2006). There is evidence from isotopic analyses that particles absorb some of the old refractory dissolved organic carbon in the deep sea (Hwang et al., 2006) and it is possible that this recalcitrant material can be utilized by fungi. In this context, it is important to keep in mind that bacteria and fungi are not always in competition with each other but that both may contribute to the degradation and benefit from each other's breakdown products in a mutualistic rather 
Table 1 Biomass (carbon) ratios of labyrinthulomycetes (LabY) and fungi (PF2) to prokaryotes

\begin{tabular}{lcccccc}
\hline $\begin{array}{c}\text { Group } \\
\text { Average volume V\&P } \\
\left(\mu \mathrm{m}^{3}\right)\end{array}$ & $\begin{array}{c}\text { Carbon range } \\
\text { N\&ST }(p g)\end{array}$ & $\begin{array}{c}\text { Carbon range M\&L } \\
(p g)\end{array}$ & $\begin{array}{c}\text { Carbon V\&P } \\
(p g)\end{array}$ & $\begin{array}{c}\text { Biomass ratio } \\
\text { N\&ST }\end{array}$ & $\begin{array}{c}\text { Biomass ratio } \\
\text { M\&L }\end{array}$ & $\begin{array}{c}\text { Biomass ratio } \\
\text { V\&P }\end{array}$ \\
\hline LabY & 106 & $5.83-23.90$ & $7.42-33.39$ & 9.48 & $0.23-0.95$ & $0.29-1.29$ \\
PF2 & 115 & $6.33-25.95$ & $8.05-36.23$ & 10.13 & $0.35-1.42$ & $0.44-1.98$ \\
\hline
\end{tabular}

Calculations were based on 0.1-0.41 $\mathrm{g} \mathrm{cm}^{-3}$ dry weight to wet volume (van Veen and Paul, 1979), and 0.2-0.9 g dry weight $\mathrm{cm}^{-3}$ wet volume (Newell and Statzell-Tallman, 1982). Note: $1 \mathrm{~g} \mathrm{~cm}^{-3}=1 \mathrm{pg} \mathrm{mm}^{-3}$. Dry weight conversion to carbon was 55\% for Cryptococcus albidus (shake culture only) (van Veen and Paul, 1979), and 35\% (Newell and Statzell-Tallman, 1982). Carbon values were also obtained from volume using the equation $C(\mathrm{pg})=0.216 \times$ volume $^{0.811}\left(\mu \mathrm{m}^{3}\right)$ for non-diatom protists (Menden-Deuer and Lessard, 2000). The same equations were applied to both groups of organisms. For bacteria, 20 fg per cell was assumed although this may be an overestimation of bacterial carbon in the deep sea (Ducklow and Carlson, 1992; Fukuda et al. 1998). Biomass ratio =C of eukaryotic microbes/C of prokaryotes (V\&P: van Veen and Paul (1979); N\&ST: Newell and Statzell-Tallman (1982); M\&L: Menden-Deuer and Lessard (2000)).

than antagonistic manner (Frey-Klett et al., 2011). Deep-sea POM has a high C:N ratio (Baltar et al., 2010). As fungi have a higher C:N ratio than bacteria ( 10 vs 5), using substrates with high $\mathrm{C}: \mathrm{N}$ ratios could give them a stoichiometric advantage over bacteria (Wang et al., 2012), although this view is not universally accepted (de Vries et al., 2006). Although fungi may contribute to the degradation of particles in the water column, there is also the intriguing possibility that their hyphen stabilize marine snow as they do with soil particles (Chenu and Stotzky, 2002). Fungal hyphae permeating the particle matrix was shown in Jobard et al. (2010) for 'lake snow'.

Fungi in deep-sea sediments and the deep biosphere dominate among active eukaryotes (Takishita et al., 2006; Edgcomb et al., 2011a) where they also dominate active eukaryotic gene expression in metatranscriptomes (Orsi et al., 2013). However, there is considerable genetic separation between benthic and pelagic fungal groups, implying that pelagic fungi are not merely resuspended benthic fungi (Tisthammer et al., 2016). In fact, pelagic fungal abundance and diversity are influenced by environmental factors such as freshwater input, temperature and increases in POM (Taylor and Cunliffe, 2016). Specifically, chytrid fungi that are both parasites and decomposers of phytoplankton increase in numbers during diatom blooms (Taylor and Cunliffe, 2016). Other pelagic environments where fungi are found in large numbers are on Trichodesmium sp. colonies (Sheridan et al., 2002) and in the surface waters of upwelling regions where fungi episodically exceed prokaryote biomass (Gutiérrez et al., 2011). Recently, a survey of bathypelagic eukaryotic microbes concluded that Basidiomycota (a major group of fungi) are among the four most dominant groups (Pernice et al., 2016). That study did not distinguish between marine snow and ambient water but screened their samples through a $20 \mu \mathrm{m}$ mesh. While screening will prevent most metazoans from entering the sample, some marine snow will fragment and associated organisms will be mixed into the sample. Given our result of an extreme enrichment of fungi on marine snow, it is very likely that fungi in these samples came primarily from marine snow. The variability in taxonomic composition of eukaryotic microbes was high in that study with much of the variance explained by water mass (Pernice et al., 2016). As the amount of deep-sea marine snow changes dramatically by water mass and location (Bochdansky et al., 2010, 2016), some of the high variability in microbial eukaryotes is very likely due to the relative abundance and type of marine snow in these layers.

\section{Labyrinthulomycetes}

This group is even less studied in marine pelagic environments than fungi. Methods previously used in pelagic environments were either most probable number estimates using pollen as bait or growth substrate or the Acriflavine direct detection method based on sulfated polysaccharides in their cell walls (Raghukumar, 2002). The first time CARD-FISH used to systematically evaluate labyrinthulomycetes in the deep-sea water column was Morgan-Smith et al. (2013) using the LabY probe (Stokes et al., 2002). Cells of this group have been reported to occur at higher numbers than fungi in the water column (Raghukumar, 2002). In our analysis, labyrinthulomycetes were approximately equally abundant as fungi on the $0.2 \mu \mathrm{m}$ filters and less enriched than fungi on marine snow (Figure 4). Of the labyrinthulomycetes, the thraustochytrids are the most dominant group in pelagic marine systems, and they are often associated with phytodetritus but are interestingly suppressed during intense phytoplankton blooms (Raghukumar, 2002). Thraustochytrids and their 18S rRNA sequences have been found to be abundant in the bathypelagic environment down to 4000 m (Gaertner, 1982; López-García et al., 2001). Thraustochytrids are extremely well adapted to cold temperatures and high pressures (Bahnweg and Sparrow, 1974; Riemann and Schaumann, 1993; Ragunkumar and Ragunkumar, 1999), and have even been found in dense clusters in Antarctic sediments (Riemann and Schrage, 1983). They have been suggested to be important agents in the degradation of organic material on deep-sea particles (Raghukumar, 2002) as they are an important group 
of decomposers of coastal leaf litter and phytoplankton in sediments (Bongiorni, 2012). Because many are also parasitic or symbiotic (Damare and Raghukumar, 2010), thraustochytrids' ecological role cannot be inferred from the data at hand. However, their large biomass contribution to microbes associated with particles suggests a substantial role in deep-sea biogeochemical processes.

\section{Biomass calculations}

Carbon ratios of fungi and labyrinthulomycetes to prokaryotes are shown in Table 1 . We used various conversion factors; however, the individual biomass estimates are very close to each other (Table 1). The carbon estimates for labyrinthulomycetes in this study are close to those previously determined for thraustochytrids (Kimura et al., 1999). Previous estimates of the contribution of thraustochytrids to total decomposer biomass (bacteria+protists) ranged from 3.5 to $29 \%$ (Kimura et al., 1999). In another study, the biomass of thraustochytrids was $\sim 10 \%$ to $\sim 100 \%$ of that of bacterial biomass (Damare and Raghukumar, 2008). Our calculations suggest that labyrinthulomycete biomass is approximately equal to that of prokaryote biomass on bathypelagic marine snow. If we combine the biomasses of fungi and labyrinthulomycetes, then eukaryotic saprotrophs exceed prokaryotes in terms of biomass, even when we exclude all other eukaryotic microbes that are present on particles. The biomass distribution of eukaryotic microbes on deep-sea marine snow is therefore much more similar to the biomass distribution in typical surface waters where eukaryotic microbes (including primary producers) exceed prokaryotic biomass (for example, Gasol et al., 1997; Church, 2008). While some misclassification of taxa by means of CARD-FISH is inevitable due to errors when there is not a perfect sequence match, it is important to emphasize that the distinction between prokaryotes and eukaryotic microbes is very robust, as only those organisms were considered eukaryotic microbes that had both a cell body hybridizing with the probes and a clearly visible nucleus inside that (Figure 3).

\section{Colonization of particles by eukaryotic microbes}

Laboratory-made marine snow in rolling tanks is quickly colonized by heterotrophic protists such as flagellates, amoeba and ciliates (Artolozaga et al., 1997) for which enrichment factors range from 5 to 10 000 (Silver et al., 1978; Caron et al., 1982; Artolozaga et al., 1997). The species composition on particles is more closely related to that found in benthic habitats than in pelagic habitats (Artolozaga et al., 1997). For instance, pelagic amoeba are typically found associated with aggregates (Arndt, 1993; Rogerson et al., 2003), and some amoeboidtype shapes were indeed present on the bathypelagic particles examined here (Figures $3 \mathrm{i}$ and $\mathrm{j}$ ).
The conclusion that marine snow is a unique microenvironment for eukaryotic microbes also resonates with earlier findings of highly enriched metazoan plankton, some of which are almost exclusively found on marine snow such as acoel turbellarians and nectochaeta larvae of polychaetes (Bochdansky and Herndl, 1992). All these indicate that marine snow provides a benthos-like yet unique habitat in the water column.

\section{Comparison between CARD-FISH and amplicon sequencing}

There are similarities and discrepancies in the relative abundance of eukaryotic microbes in the deep sea between methods when comparing amplicon sequencing and direct cell counts. As shown above, the high number of Basidiomycota in deepsea samples (Pernice et al., 2016) is supported by our findings of a large number of fungi. Direct counts and $16 S / 18 S$ diversity approaches also agree in the relative abundance of diplonemids for deep-sea environments (Lara et al., 2009; Morgan-Smith et al., 2013; Lukeš et al., 2015; Pernice et al., 2016). In contrast, group 2 alveolates that represent a large portion in deep-sea clone libraries (for example, Countway et al., 2005; Pernice et al., 2016) make a relatively smaller fraction in deep-sea samples when enumerated by CARD-FISH (Morgan-Smith et al., 2013). Ciliates are dominant in clone libraries of the deep sea (for example, Countway et al., 2005; Pernice et al., 2016). Ciliate abundances are high in oxygen-depleted waters where they either form symbiotic relationships with prokaryotes (Edgcomb et al., 2011b; Orsi et al., 2013) or feed on them (Anderson et al., 2012). However, ciliates are rare in the typical high-oxygen deep-sea samples and when counts are based on morphological criteria (Aristegui et al., 2009). There are considerable biases that lead to overrepresentation of some groups in the analysis of $18 \mathrm{~S}$ rRNA gene libraries discussed in detail in Koid et al. (2012), including multiple genome copies found especially in alveolates (for example, Dinophycea and Ciliophora). Unless the actual cell numbers can be independently verified by direct cell counts using suitable CARD-FISH probes, results of the relative dominance of some eukaryotic groups in deep-sea samples need to be treated with great caution.

\section{Conclusions}

There is growing evidence that neutrally buoyant or slowly-sinking particles augmented by an active community of chemosynthetic and carbon-fixing microorganisms need to be considered in budget calculations of the deep sea (Baltar et al., 2009, 2010; Bochdansky et al., 2010; Burd et al., 2010; Herndl and Reinthaler, 2013). The high TEP content of deepsea macroscopic particles, especially those in the 
range of $400 \mu \mathrm{m}$ to several $\mathrm{mm}$ in size, could contribute to that buoyancy (Atsetsu-Scott and Passow, 2004; Bochdansky et al., 2016). Slowlysinking and neutrally buoyant particles would allow sufficient time for complex eukaryotic microbial communities to form on the high organic nutrients available in particle matrix and pore water. The ratios between eukaryotes and prokaryotes in our $0.2 \mu \mathrm{m}$ filter samples were low and similar to those typically found in the deep ocean (Aristegui et al., 2009; Morgan-Smith et al., 2013; Pernice et al., 2015). In contrast, the bathypelagic marine snow samples abounded with eukaryotic microbes with eukaryote:prokaryote ratios much higher and closer to those found in surface waters. At these high biomass levels, eukaryotic microbes could significantly contribute to particle solubilization and remineralization, and to the control of prokaryote abundances through grazing, all of which strongly suggests that eukaryotic microbes can no longer be considered sideshows to ecosystem processes of the deep sea.

\section{Conflict of Interest}

The authors declare no conflict of interest.

\section{Acknowledgements}

We thank the crew of the RV Pelagia. We are grateful to Uta Passow (University of California, Santa Barbara) for suggesting the use of EDTA to make accumulated TEP on the $30 \mu \mathrm{m}$ filters sufficiently porous for DAPI and CARDFISH probes. This study was funded by the National Science Foundation project \#1235169 to ABB and by the European Research Council under the European Community's Seventh Framework Program (FP7/2007-2013)/ERC grant agreement No. 268595 (MEDEA project) to GJH.

\section{References}

Alldredge AL, Passow U, Logan BE. (1993). The abundance and significance of a class of large, transparent organic particles in the ocean. Deep-Sea Res I 40: 1131-1140.

Alldredge AL, Silver MW. (1988). Characteristics, dynamics and significance of marine snow. Prog Oceanogr 20: 41-82.

Alldredge AL, Youngbluth MJ. (1985). The significance of macroscopic aggregates (marine snow) as sites for heterotrophic bacterial production in the mesopelagic zone of the subtropical Atlantic. Deep-Sea Res 32: 1445-1456.

Anderson R, Winter C, Jürgens K. (2012). Protist grazing and viral lysis as prokaryotic mortality factors as Baltic Sea oxic-anoxic interfaces. Mar Ecol Prog Ser 467: $1-14$.

Aristegui J, Gasol J, Duarte C, Herndl GJ. (2009). Microbial oceanography of the dark ocean's pelagic realm. Limnol Oceanogr 54: 1501-1529.
Arndt H. (1993). A critical review of the importance of rhizopods (naked and testate amoebae) and actinopods (heliozoan) in lake plankton. Mar Microb Food Webs 7: 3-29.

Arndt H, Hausmann K, Wolf M. (2003). Deep-sea heterotrophic nanoflagellates of the Eastern Mediterranean Sea: qualitative and quantitative aspects of their pelagic and benthic occurrence. Mar Ecol Prog Ser 256: $45-56$.

Artolozaga I, Ayo B, Latatu A, Azua I, Unanue M, Iriberri J. (2000). Spatial distribution of protists in the presence of macroaggregates in a marine system. FEMS Microbiol Ecol 33: 191-196.

Artolozaga I, Santamaria E, Lopez A, Ayo B, Iriberri J. (1997). Succession of bacterivorous protists on laboratory-made marine snow. J Plankton Res 19: 1429-1440.

Atsetsu-Scott K, Passow U. (2004). Ascending marine particles: significance of transparent exopolymer particles (TEP) in the upper ocean. Limnol Oceanogr 49: 741-748.

Bahnweg G, Sparrow FK. (1974). Four new species of thraustochytrium from Antarctic regions, with notes on the distribution of zoosporic fungi in the Antarctic marine ecosystems. Am J Bot 61: 754-766.

Baltar F, Arístegui J, Gasol JM, Sintes E, Herndl GJ. (2009). Evidence of prokaryotic metabolism on suspended particulate organic matter in the dark waters of the subtropical North Atlantic. Limnol Oceanogr 54: 182-193.

Baltar F, Arístegui J, Sintes E, Gasol JM, Reinthaler T, Herndl GJ. (2010). Significance of non-sinking particulate organic carbon and dark CO2 fixation to heterotrophic carbon demand in the mesopelagic northeast Atlantic. Geophys Res Lett 37: L09602.

Bar-Zeev E, Passow U, Castrillon SR, Elimelech M. (2015). Transparent exopolymer particles: From aquatic environments and engineered systems to membrane biofouling. Environ Sci Technol 49: 691-707.

Bochdansky AB, Bollens SM. (2004). Relevant scales in zooplankton ecology: Distribution, feeding, and reproduction of the copepod Acartia hudsonica in response to thin layers of the diatom Skeletonema costatum. Limnol Oceanogr 49: 625-636.

Bochdansky AB, Clouse MA. (2015). A new tracer to estimate community predation rates of phagotrophic protists. Mar Ecol Prog Ser 524: 55-69.

Bochdansky AB, Clouse MA, Herndl GJ. (2016). Dragon kings of the deep sea: marine particles deviate markedly from the common number-size spectrum. Sci Rep 6: 22633.

Bochdansky AB, Herndl GJ. (1992). Ecology of amorphous aggregations (marine snow) in the Northern Adriatic Sea. V. Role of fecal pellets in marine snow. Mar Ecol Prog Ser 89: 297-303.

Bochdansky AB, Huang L. (2010). Re-evaluation of the EUK516 probe for the domain Eukarya results in a suitable probe for the detection of kinetoplastids, an important group of parasitic and free-living flagellates. J Eukaryot Microbiol 57: 229-235.

Bochdansky AB, van Aken HM, Herndl GJ. (2010). Role of macroscopic particles in deep-sea oxygen consumption. Proc Natl Acad Sci 107: 8287-8291.

Boenigk J, Arndt H. (2002). Bacterivory by heterotrophic flagellates: community structure and feeding strategies. Anton Van Leeuwenhoek 81: 465-480. 
Bongiorni L. (2012). Thraustochytrids, a neglected component of organic matter decomposition and food webs in marine sediments. In: Raghukumar C (ed), Biology of Marine Fungi, Progress in Molecular and Subcellular Biology, Springer-Verlag: Heidelberg, Berlin, Germany, pp 1-13.

Bratbak M. (1985). Bacterial biovolume and biomass estimations. Appl Environ Microbiol 49: 1488-1493.

Buesseler KO, Antia AN, Chen M, Fowler SW, Gardner WD, Gustafsson O et al. (2007). An assessment of the use of sediment traps for estimating upper ocean particle fluxes. J Mar Res 65: 345-416.

Buesseler KO, Boyd PW. (2009). Shedding light on processes that control particle export and flux attenuation in the twilight zone of the open ocean. Limnol Oceanogr 54: 1210-1232.

Burd AB, Hansell DA, Steinberg DK, Anderson TR, Arístegui J, Baltar F et al. (2010). Assessing the apparent imbalance between geochemical and biochemical indicators of meso- and bathypelagic biological activity: What the @\$\#! is wrong with present calculations of carbon budgets? Deep-Sea Res II 57: 1557-1571.

Caron DA. (1987). Grazing of attached bacteria by heterotrophic microflagellates. Microb Ecol 13: 203-218.

Caron DA, Davis PG, Madin LP, Sieburth JM. (1982). Heterotrophic bacteria and bacterivorous protozoa in oceanic macroaggregrates. Science 218: 795-797.

Cavaliere R, Ball JL, Turnbull L, Whitchurch CB. (2014). The biofilm matrix destabilizers, EDTA and DNasel, enhance the susceptibility of nontypeable Hemophilus influenza biofilms to treatment with ampicillin and ciprofloxacin. MicrobiologyOpen 3: 557-567.

Chavez-Dozal A, Gorman C, Erken M, Steinberg PD, McDougald D, Nishiguchi MK. (2013). Predation response of Vibrio fischeri biofilms to bacterivorus protists. Appl Environ Microbiol 79: 553-558.

Chenu C, Stotzky G. (2002). Interactions between microorganisms and soil particles: an overview. In: Huang PM, Bollag J-M, Senesi N (eds), Interactions between Soil Particles and Microorganisms. John Wiley and Sons: New York, pp 3-40.

Church MJ. (2008). Resource control of bacterial dynamics in the sea. In: Kirchman DL (ed), Microbial Ecology of the Oceans, 2nd edn, John Wiley \& Sons, Inc.: Hoboken, NJ, USA, pp 335-382.

Ciobanu M-C, Burgaud G, Dufresne A, Breuker A, Rédou V, Maamar SB et al. (2014). Microorganisms persist at record depths in the subseafloor of the Canterbury Basin. ISME J 8: 1370-1380.

Clipson N, Otte M, Landy E. (2006). Biogeochemical roles of fungi in marine and estuarine habitats. In: Gadd GM (ed.). Fungi in Biogeochemical Cycles. Cambridge University Press: CA, USA, pp 436-461.

Countway PD, Gast RJ, Savai P, Caron DA. (2005). Protistan diversity estimates based on $18 \mathrm{~S}$ rDNA from seawater incubations in the western North Atlantic. J Eukaryot Microbiol 52: 95-106.

Damare V, Raghukumar S. (2010). Association of the stramenopilan protists, the aplanochytrids, with zooplankton of the equatorial Indian Ocean. Mar Ecol Prog Ser 399: 53-68.

Damare V, Raghukumar S. (2008). Abundance of thraustochytrids and bacteria in the equatorial Indian Ocean, in relation to transparent exopolymeric particles (TEP). FEMS Microbiol Ecol 65: 40-49. de Vries FT, Hoffland E, van Eekeren N, Brussard L, Bloem J. (2006). Fungal/bacterial ratios in grasslands with contrasting nitrogen management. Soil Biol Biochem 38: 2092-2103.

Ducklow HW, Carlson CA. (1992). Oceanic bacterial production. In: Marshall KC (ed.). Advances in Microbial Ecology. Plenum Press: New York, pp 113-181.

Edgcomb VP, Beaudoin D, Gast R, Biddle JF, Teske A. (2011a). Marine subsurface eukaryotes: the fungal majority. Environ Microbiol 13: 172-183.

Edgcomb VP, Orsi W, Bunge J, Jeon S, Christen R, Leslin C et al. (2011b). Protistan microbial observatory in the Cariaco Basin, Caribbean. I. Pyrosequencing vs Sanger insights into species richness. ISME $J$ 5: 1344-1356.

Eloe EA, Fadrosh DW, Novotny M, Zeigler Allen L, Kim M, Lombardo M-J et al. (2011). Going deeper: Metagenome of a hadopelagic microbial community. PLoS One 6: e20388.

Fontanez KM, Eppley JM, Samo TJ, Karl DM, Delong EF. (2015). Microbial community structure and function on sinking particles in the North Pacific Subtropical Gyre. Front Microbiol 6: 469.

Frey-Klett P, Burlinson P, Deveau A, Barret M, Tarkka M, Sarniguet A. (2011). Bacterial-fungal interactions: Hyphens between agricultural, clinical, environmental, and food microbiologists. Microbiol Mol Biol Rev 75: 583-609.

Fuhrman JA, Noble RT. (1995). Viruses and protists cause similar bacterial mortality in coastal seawater. Limnol Oceanogr 40: 1236-1242.

Fukuda R, Ogawa H, Nagata T, Koike I. (1998). Direct determination of carbon and nitrogen contents of natural bacterial assemblages in marine environments. Appl Environ Microbiol 64: 3352-3358.

Gaertner A. (1982). Lower marine fungi from the Northwest African upwelling areas and from the Atlantic off Portugal. Meteor Forsch Ergebn D 34: 9-30.

Gasol JM, del Giorgio PA, Duarte DM. (1997). Biomass distribution in marine planktonic communities. Limnol Oceanogr 42: 1353-1363.

Gutiérrez MH, Pantoja S, Tejos E, Quiñones RA. (2011). The role of fungi in processing marine organic matter in the upwelling ecosystem off Chile. Mar Biol 158: 205-219.

Hassett BT, Gradinger R. (2016). Chytrids dominate arctic marine fungal communities. Environ Microbiol 18: 2001-2009.

Herndl GJ, Reinthaler T. (2013). Microbial control of the dark end of the biological pump. Nat Geosci 6: $718-724$.

Honjo S, Manganini SJ, Krishfield RA, Francois R. (2008). Particulate organic carbon fluxes to the ocean interior and factors controlling the biological pump: a synthesis of global sediment trap programs since 1983. Prog Oceanogr 76: 217-285.

Hugenholtz P, Tyson GW, Blackall L. (2001). Design and evaluation of $16 \mathrm{~S}$ rRNA-targeted oligonucleotide probes for fluorescence in situ hybridizationLieberman BA (ed), Methods in Molecular Biology, vol. 176. Steroid Receptor Methods: Protocols and Assays. Humana Press Inc: Totowa, NJ, pp 29-41.

Hwang J, Druffel ERM, Bauer JE. (2006). Incorporation of aged dissolved organic carbon (DOC) by oceanic particulate organic carbon (POC): an experimental approach using natural carbon isotopes. Mar Chem 98: $315-322$. 
Jobard M, Rasconi S, Sime-Ngando T. (2010). Diversity and functions of microscopic fungi: A missing component in pelagic food webs. Aquat Sci 72: 255-268.

Kimura H, Fukuba T, Naganuma T. (1999). Biomass of the thraustochytrid protoctists in coastal water. Mar Ecol Prog Ser 189: 27-33.

Kirchman DL. (2008). Introduction and overview. In: Kirchman DL (ed.). Microbial Ecology of the Oceans, 2nd edn.pp 1-26.

Koeve W, Ducklow HW. (2001). JGOFS research in the North Atlantic Ocean: a decade of research, synthesis and modelling. Deep-Sea Res II 48: 2141-2424.

Koid A, Nelson WC, Mraz A, Heidelberg KB. (2012). Comparative analysis of eukaryotic marine microbial assemblages from 18S rRNA gene and gene transcript clone libraries by using different methods of extraction. Appl Environ Microbiol 78: 3958-3965.

Kutty SN, Philip R. (2009). Marine yeasts - a review. Yeast 25: $465-483$.

Lara E, Moreira D, Vereshchaka A, Lopez-Garcia P. (2009). Pan-oceanic distribution of new highly diverse clades of deep-sea diplonemids. Environ Microbiol 11: $47-55$.

Le Calvez T, Burgaud G, Mahé S, Barbier G, Vandenkoornhuyse P. (2009). Fungal diversity in deep-sea hydrothermal ecosystems. Appl Environ Microbiol $\mathbf{7 5}$ 6415-6421.

Lloyd M. (1967). Mean crowding. J Anim Ecol 36: 1-30.

López-García P, Rodríguez-Valera F, Pedrós-Alió C, Moreira D. (2001). Unexpected diversity of small eukaryotes in deep-sea Antarctic plankton. Nature 409: 603-607.

Lukeš J, Flegontova O, Horák A. (2015). Quick guide: Diplonemids. Current Biol 25: R1-R3.

Martin JH, Knauer GA, Karl DM, Broenkow WW. (1987). VERTEX: carbon cycling in the northeast Pacific. DeepSea Res 34: 267-285.

Menden-Deuer S, Lessard EJ. (2000). Carbon to volume relationships for dinoflagellates, diatoms, and other protist plankton. Limnol Oceanogr 45: 569-579.

Morgan-Smith D, Clouse MA, Herndl GJ, Bochdansky AB. (2013). Diversity and distribution of microbial eukaryotes in the deep tropical and subtropical North Atlantic Ocean. Deep-Sea Res I 78: 58-69.

Mukherjee I, Hodoki Y, Nakano S. (2015). Kinetoplastid flagellates overlooked by universal primers dominate in the oxygenated hypolimnion of Lake Biwa, Japan. FEMS Microbiol Ecol 91: 1-11.

Newell SY. (1994). Ecomethodology for organoosmotrophs: prokaryotic unicellular versus eukaryotic mycelial. Microb Ecol 28: 151-157.

Newell SY, Statzell-Tallman A. (1982). Factors for conversion of fungal biovolume values to biomass, carbon and nitrogen: variation with mycelial ages, growth conditions, and strains of fungi from a salt marsh. OIKOS 39: 261-268.

Orsi WD, Edgcomb VP, Christman GD, Biddle JF. (2013). Gene expression in the deep biosphere. Nature 499: 205-209.

Orsi WD, Smith JM, Liu S, Liu Z, Sakamato CM, Wilken S et al. (2016). Diverse, uncultivated bacteria and archaea underlying the cycling of dissolved protein in the ocean. ISME J 10: 2158-2173.

Pernice MC, Giner CR, Logares R, Perera-Bel J, Acinas SG, Duarte CM et al. (2016). Large variability of bathypelagic microbial eukaryotic communities across the world's oceans. ISME J 10: 945-958.

Pernice MC, Irene Forn I, Gomes A, Lara E, Alonso-Sáez L, Arrieta JM et al. (2015). Global distribution of planktonic heterotrophic protists in the deep ocean. ISME J 9: 782-792.

Raghukumar S. (2002). Ecology of the marine protists, the Labyrinthulomycetes (Thraustochytrids and Labyrinthulids). Eur J Protistol 38: 127-145.

Raghukumar S, Raghukumar C. (1999). Thraustochytrid fungoid protists in faecal pellets of the tunicate Pegea confoedereta, their tolerance to deep-sea conditions and implication in degradation processes. Mar Ecol Prog Ser 190: 133-140.

Rédou V, Navarri M, Meslet-Cladière L, Barbier G, Burgaud G. (2015). Species richness and adaptation of marine fungi from deep-subseafloor sediments. Appl Environ Microbiol 81: 3571-3583.

Richards TA, Leonard G, Mahé F, del Campo J, Romac S, Jones MDM et al. (2015). Molecular diversity and distribution of marine fungi across 130 European environmental samples. Proc Biol Sci 282: pii: 20152243.

Riemann F, Schaumann K. (1993). Thraustochytrid protists in Antarctic fast ice? Antarctic Sci 5: 279-280.

Riemann F, Schrage M. (1983). On a mass occurrence of a thraustochytrid protist (fungi or rhizopodan protozoa) in an Antarctic anaerobic marine sediment. Veröff Inst Meeresforsch Bremerh 19: 191-202.

Rogerson A, Anderson OR, Vogel C. (2003). Are planktonic naked amoebae predominantly floc associated or free in the water column? J Plankton Res 25: 1359-1365.

Salazar G, Cornejo-Castillo FM, Borrull E, Díez-Vives C, Lara E, Vaqué D et al. (2015). Particle-association lifestyle is a phylogenetically conserved trait in bathypelagic prokaryotes. Mol Ecol 24: 5692-5706.

Sheridan CC, Steinberg DK, Kling GW. (2002). The microbial and metazoan community associated with colonies of Trichodesmium spp.: a quantitative survey. I Plankton Res 24: 913-922.

Silver M. (2015). Marine snow: a brief historical sketch. Limnol Oceanogr Bull 24: 5-10.

Silver MW, Alldredge AL. (1981). Bathypelagic marine snow: deep-sea algal and detrital community. J Mar Res 39: 501-530.

Silver MW, Shanks AL, Trent JD. (1978). Marine snow: microplankton habitat and source of small-scale patchiness in pelagic populations. Science 201: 371-373.

Stokes NA, Ragone Calvo LM, Reece KS, Burreson EM. (2002). Molecular diagnostics, field validation, and phylogenetic analysis of Quahog Parasite Unknown (QPX), a pathogen of the hard clam Mercenaria mercenaria. Dis Aquat Organ 52: 233-247.

Takishita K, Tsuchiya M, Reimer JD, Maruyama T. (2006). Molecular evidence demonstrating the basidiomycetous fungus Cryptococcus curvatus is the dominant microbial eukaryote in sediment at the Kuroshima Knoll methane seep. Extremophiles 10: 165-169.

Taylor JD, Cunliffe M. (2016). Multi-year assessment of coastal planktonic fungi reveals environmental drivers of diversity and abundance. ISME J 10: 2118-2128.

Teira E, Reinthaler T, Pernthaler A, Pernthaler J, Herndl GJ. (2004). Combining catalyzed reporter depositionfluorescence in situ hybridization and microautoradiography to detect substrate utilization by bacteria and archaea in the deep ocean. Appl Environ Microbiol 70: 4411-4414. 
Tisthammer KH, Cobian GM, Amend AS. (2016). Global biogeography of marine fungi is shaped by the environment. Fungal Ecol 19: 39-46.

Turley CM, Lochte K, Patterson DJ. (1988). A barophilic flagellate isolated from $4500 \mathrm{~m}$ in the mid-North Atlantic. Deep-Sea Res 35: 1079-1092.

van Aken HM. (2000). The hydrography of the mid-latitude northeast Atlantic Ocean I: the deep-water masses. Deep-Sea Res I 47: 757-788. van Veen JA, Paul EA. (1979). Conversion of biovolume measurements of soil organisms, grown under various moisture tensions, to biomass and their nutrient content. Appl Environ Microbiol 37: 686-692.

Wang G, Wang X, Liu X, Li Q. (2012). Diversity and biogeochemical function of planktonic fungi in the ocean. In: Raghukumar C (ed), Biology of Marine Fungi. Progress in Molecular and Subcellular Biology, SpringerVerlag: Heidelberg, Berlin, Germany, Vol. 53, pp 71-88.

Supplementary Information accompanies this paper on The ISME Journal website (http://www.nature.com/ismej) 